\title{
Genetic Variability among Landraces of Sesame (Sesamum indicum L.)
}

\section{U. K. Singh ${ }^{\text {** }}$, Niraj Kumar ${ }^{2}$, Rajesh Kumar ${ }^{3}$, Vikram Bharati ${ }^{4}$ and Sumeet Kumar Singh ${ }^{5}$}

${ }^{1}$ Department of Plant Breeding \& Genetics, Tirhut College of Agriculture, Dholi, Muzaffarpur, Dr Rajendra Prasad Central Agricultural University, Bihar-848 125, India

${ }^{2}$ Department of Agronomy, Tirhut College of Agriculture, Dholi, Muzaffarpur, Dr Rajendra

Prasad Central Agricultural University, Bihar - 848 125, India

${ }^{3}$ Department of Seed Science Technology, Tirhut College of Agriculture, Dholi, Muzaffarpur, Dr Rajendra Prasad Central Agricultural University, Bihar - 848 125, India

*Corresponding author

\section{A B S T R A C T}

Keywords

Sesame, Genetic

Variability,

Landraces

Article Info

\section{Accepted:}

18 March 2020

Available Online:

10 April 2020
Twenty one genotypes including check Krishna were evaluated in randomized block design with three replications during kharif-2017 at research farm of TCA, Dholi for estimation of genetic variability among them. Genotypes varied significantly for all the morpho-physiological characters indicating the presence of considerable variability among the genotypes. Significant bidirectional shift was observed in the mean values as compared to better check, thus provided scope for selection. A close proximity between PCV and GCV indicated strong base of genetic component in phenotypic expression of all the characters under study. High heritability coupled with high genetic advance for yield traits suggested the preponderance of additive gene effect in the expression of these characters.

\section{Introduction}

Sesame is a high value food crop which is an important source of edible oil and is also used as a spice. India is the largest producer of Sesame covering $42 \%$ of world's Sesame area and 27 per cent of the production. Genetic and environmental factors influence the oil content and fatty acid compositions of sesame (Carlsson et al., 2008). Generally yield contributing attributes, their genetic nature and magnitude of association are responsible for realization of yield potential. Therefore, the present investigation was taken up to assess the extent of genetic variability for yield and yield attributes.

\section{Materials and Methods}

The experiment was carried out with twenty one genotypes including check Krishna following RBD with three replications during kharif, 2017 at TCA, Dholi, Bihar. Data on yield attributing traits were recorded. Mean 
data of six plants in all the replications were used for statistical analysis for eleven characters. The analysis of variance (ANOVA) was worked out for each character as per methodology advocated by Panse and Sukhatme (1967).

\section{Results and Discussion}

According to the mean performance, a wide range of variation was found for most of the characters among genotypes. The highest phenotypic variability was recorded for plant height (1090.88). The genotypic variance for all the eleven characters; days to 50 per cent flowering, plant height, number of branches per plant, days to maturity, productive branches per plant, productive capsules per plant, number of seeds per capsule, 1000 seed weight, biological yield per plant, harvest index, and seed yield per plant were recorded as $17.31,1202.58,1.48,52.08,1.21,422.50$, $81.41, \quad 0.19, \quad 11.07, \quad 78.35$ and 2.49, respectively.

The narrow differences between PCV and GCV were recorded for almost all the traits under study. A wide range of PCV was observed for the traits under investigation ranged from 6.98 (days to 50 per cent flowering) to 53.39 (seed yield per plant). High PCV was recorded for plant height (26.47), number of branches per plant (31.83), number of productive branches per plant (31.62), number of productive capsules per plant (44.58), biological yield (21.17), harvest index (47.59) and seed yield per plant (53.39) (Table 1).

Table.1 Mean performance of twenty one genotypes of sesame for eleven characters

\begin{tabular}{|c|c|c|c|c|c|c|c|c|c|c|c|}
\hline $\begin{array}{l}\text { Characters } \\
\text { Genotypes }\end{array}$ & $\begin{array}{c}\text { Days to } \\
50 \% \\
\text { Flowering }\end{array}$ & $\begin{array}{c}\text { Plant } \\
\text { Height } \\
(\mathbf{c m})\end{array}$ & $\begin{array}{c}\begin{array}{c}\text { Number } \\
\text { of } \\
\text { Branches/ } \\
\text { Plant }\end{array}\end{array}$ & $\begin{array}{l}\text { Days to } \\
\text { Maturity }\end{array}$ & $\begin{array}{c}\text { Number of } \\
\text { Productive } \\
\text { Branches/ } \\
\text { Plant }\end{array}$ & $\begin{array}{c}\text { Number of } \\
\text { Productive } \\
\text { Capsules/ } \\
\text { Plant }\end{array}$ & $\begin{array}{c}\text { Number } \\
\text { of Seeds } \\
\text { /Capsule }\end{array}$ & $\begin{array}{c}1000 \\
\text { Seed } \\
\text { Weight } \\
\text { (g) }\end{array}$ & $\begin{array}{c}\text { Biological } \\
\text { Yield } \\
\text { (dry } \\
\text { Matter/ } \\
\text { Plant (g) }\end{array}$ & $\begin{array}{c}\text { Harvest } \\
\text { Index } \\
(\%)\end{array}$ & $\begin{array}{l}\text { Seed } \\
\text { Yield/ } \\
\text { Plant } \\
(\mathrm{g})\end{array}$ \\
\hline NIC-16073 & 61.33 & $144.27^{*}$ & 2.17 & 86.33 & 1.83 & 31.00 & 48.67 & 2.51 & 17.73 & 10.10 & 1.77 \\
\hline S-0175 & 56.33 & $141.30^{*}$ & 1.97 & 81.33 & 1.97 & 24.67 & 39.00 & 2.20 & 16.74 & 10.02 & 1.67 \\
\hline NIC-13586 & 64.00 & 185.50 & 5.67 & 88.33 & 5.00 & 61.33 & 57.67 & 2.36 & 20.33 & 14.96 & 3.01 \\
\hline NIC-8225 & 59.00 & $153.00^{*}$ & 5.00 & 84.00 & 4.67 & 56.67 & 56.67 & 2.18 & 15.80 & 19.53 & 3.06 \\
\hline ES-58 & 65.00 & 160.50 & 4.00 & 90.00 & 3.83 & 51.67 & 64.00 & 2.50 & 10.27 & 30.38 & 3.04 \\
\hline IC-204533 & 63.33 & $158.00^{*}$ & 6.00 & 88.33 & $5.67^{*}$ & 80.00 & 63.00 & 2.26 & 19.66 & 22.07 & 4.35 \\
\hline Lolgida Local & 57.00 & $156.33^{*}$ & 4.57 & 82.00 & 4.17 & 66.00 & 59.67 & 2.60 & 13.54 & 8.74 & 1.18 \\
\hline IC-54035 & 61.67 & $108.07^{*}$ & 4.77 & 88.33 & 3.50 & 51.33 & 59.67 & 2.01 & 14.29 & $34.09^{*}$ & 4.78 \\
\hline S-0527 & 57.33 & $107.60^{*}$ & 3.67 & 82.33 & 3.50 & 29.33 & 61.67 & 2.27 & 18.82 & 20.86 & 3.91 \\
\hline IC-81563 & 58.67 & $132.93^{*}$ & 3.90 & 84.67 & 3.50 & 82.33 & 56.33 & 2.28 & 17.11 & 27.60 & 4.71 \\
\hline Jubong Sesame & 57.33 & $131.07^{*}$ & 3.83 & 82.33 & 3.83 & 48.00 & 54.00 & 2.05 & 16.73 & 17.99 & 2.99 \\
\hline SI-1865-1-B & 61.33 & $129.90^{*}$ & 3.00 & 86.33 & 2.67 & 32.00 & 38.00 & 2.58 & 14.10 & 12.53 & 1.75 \\
\hline S-0062-A & 65.67 & $125.27^{*}$ & 3.00 & 98.00 & 3.00 & 30.33 & 53.00 & 2.22 & 10.39 & 13.71 & 1.38 \\
\hline IS-346 & 61.33 & $117.00^{*}$ & 3.03 & 100.00 & 3.00 & 47.00 & 49.33 & 2.47 & 12.76 & 13.93 & 1.75 \\
\hline NIC-17274-C & 59.00 & $102.60^{*}$ & 3.43 & 99.00 & 3.33 & 26.33 & 60.67 & 2.23 & 15.53 & 12.81 & 1.97 \\
\hline 847-1-C & 63.33 & $72.50^{*}$ & 2.57 & 99.33 & 2.17 & 15.33 & 44.67 & 2.19 & 13.03 & 7.61 & 0.98 \\
\hline IS-425-C & 59.00 & $69.73^{*}$ & 3.47 & 93.00 & 3.17 & 19.33 & 49.00 & 2.50 & 16.03 & 20.82 & 3.32 \\
\hline SI-2670 & 61.33 & $88.17^{*}$ & 2.73 & 93.33 & 2.17 & 29.33 & 46.33 & 2.19 & 11.50 & 10.94 & 1.26 \\
\hline RT-54 & $48.00^{*}$ & $107.00^{*}$ & 4.00 & $75.00^{*}$ & 3.83 & 49.67 & 51.33 & 2.92 & 17.38 & 18.12 & 3.14 \\
\hline Pragati & 56.00 & 184.33 & 4.20 & 81.33 & 3.67 & 60.00 & 67.33 & 3.40 & 18.16 & $35.89^{*}$ & $6.46^{*}$ \\
\hline Krishna & 55.00 & 176.17 & 5.40 & 80.00 & 4.67 & 76.67 & 60.67 & 3.65 & 20.17 & 27.90 & 5.62 \\
\hline Mean & 59.57 & 131.01 & 3.83 & 87.78 & 3.48 & 46.11 & 54.32 & 2.46 & 15.72 & 18.60 & 2.96 \\
\hline C.D. $5 \%$ & 1.94 & 17.44 & 0.99 & 2.73 & 0.88 & 7.75 & 8.14 & 0.30 & 2.74 & 5.46 & 0.59 \\
\hline CV & 1.97 & 8.06 & 15.65 & 1.8 & 15.27 & 10.19 & 9.08 & 7.35 & 10.58 & 17.80 & 12.02 \\
\hline \pm S.Em & 0.68 & 6.1 & 0.35 & 0.96 & 0.31 & 2.71 & 2.85 & 0.1 & 0.96 & 1.91 & 0.21 \\
\hline
\end{tabular}


The genotypic coefficient of variation was high for plant height (25.21), number of branches per plant (27.72), number of productive branches per plant (27.69), number of productive capsules per plant (43.40), harvest index (44.14) and seed yield per plant (52.02).

Both PCV and GCV estimates were high for number of capsules per plant. Similar results were also observed Revathi et al., (2012) for this character. High heritability estimates coupled with high genetic advance as per cent of mean was recorded for number of capsules per plant, seed yield per plant, total dry matter production per plant, 1000-seed weight, number of branches per plant, plant height, days to 50 per cent flowering and number of seeds per capsule. It was suggested that these characters are controlled by additive gene effects and hence simple selection may be effective to improve these characters. Days to maturity and capsule length recorded high heritability coupled with moderate genetic advance as per cent of mean indicating that these traits are conferred by additive gene effect; therefore selection is effective for these characters.

\section{References}

Panse V G and Sukhatme P V 1967. Statistical methods for Agricultural Research Works. III edition, ICAR, New Delhi.

Revathi S, Joel J A and Manivannan N 2012. Genetic variability in sesame (Sesamum indicum L.). Electronic Journal of Plant Breeding, 3: 692-694.

\section{How to cite this article:}

Singh, U. K., Niraj Kumar, Rajesh Kumar, Vikram Bharati and Sumeet Kumar Singh. 2020. Genetic Variability among Landraces of Sesame (Sesamum indicum L.). Int.J.Curr.Microbiol.App.Sci. 9(04): 2093-2095. doi: https://doi.org/10.20546/ijcmas.2020.904.251 